lack of calcium caused the liberation of something which stimulated a second heart. Some time later he had an inspiration when two memories became related in his brain. He woke up in the middle of the night with the thought that frog hearts might be used to prove chemical transmission, and he got out of bed, went to the laboratory, did the experiment and found that it worked; fiuid, collected from the heart during the stimulation of the nerves, had an action when transferred to a second heart. If he had given himself more time to think he would probably not have done this experiment, since it was unlikely that the nerve would liberate such an excess of transmitter. In 1936 Loewi was awarded a Nobel Prize jointly with $\mathrm{H}$. H. Dale for this discovery.

On March 11, 1938, the Nazis took over Austria, and at 3 a.m. the next morning storm-troopers arrested Loewi as a Jew and put him in prison. In September 1938 he was forced to leave Austria and went to Belgium, to Oxford and then to New York, where he spent the last twenty years of his life as research professor of pharmacology in the New York University Medical School. He became an American citizen in 1946 and lived happily working in the laboratory until 1955 and visiting Woods Hole each summer. He was very active mentally to the last, but became crippled as the result of a fall. $\mathrm{He}$ married Guida Goldschmidt in 1908 and had three sons and one daughter. He was in happy contact with the whole family until his death, though his wife died a year or so ago.

He was awarded the Cameron Prize in 1944 and was a foreign member of the Royal Society. Every. one who met him loved him as a man and respected him as a great man.

J. H. GADDUM

\section{Prof. B. T. P. Barker, C.B.E.}

Wrth the death of Prof. Barker on December 19, 1961, at the age of eighty-four, agricultural science has lost another of those pioneers who were responsible for the early development of the agricultural research institutes in Great Britain.

Although Barker was destined to make his career in the West Country, he was by birth, upbringing and training an Eastern Counties man. Born in Cambridge, he also received his school and university training there, at the Perse School and at Gonville and Caius College, of which he was a scholar. At the University he studied botany under the late Prof. Marshall Ward, where, after graduating in 1899, he engaged in research in mycology and held the post of demonstrator in the Department of Botany, during which period his researches were recognized by the award of the Walsingham Gold Medal in 1901.

In 1904 Barker was invited to join the staff of the recently established National Fruit and Cider Institute at Long Ashton, near Bristol, as assistant director, to be responsible for carrying out a programme of research on cider-making and ciderorcharding problems, under the direction of a consultant director, Mr. F. J. Lloyd. In the following year Mr. Lloyd relinquished his appointment, and Barker became director, with the entire responsibility for developing the research work of the Institute. Left alone, ho sought the collaboration in his scientific researches of members of the staff of the nearby University College of Bristol, and was fortunate in arousing the interest of a kindred spirit in J. $\mathrm{H}$. Priestley (later Prof. Priestley), head of the Botany Department.
Barker remained almost wholly concerned with eider problems until 1912, when the Institute became formally associated with the University of Bristol under the scheme of the Board of Agriculture for the provision of research and technical advice in agriculture and horticulture. Under this new arrangement a Department of Agriculture and Horticulture was established in the University, and Barker, as its head, was appointed professor of agricultural biology. At this time the research programme was extended to include commercial fruit culture, and the Department also became the advisory centre for agriculture and horticulture in the Bristol Province.

During the First World War, Barker was actively engaged in researches on the preservation of fruit by canning and bottling and jam and jelly manufacture, and arising from this the Chipping Campden Research Station was established in 1918 and became associated with the University of Bristol in 1921, with Barker acting as director of the Station, in addition to Long Ashton, from 1921 to 1935.

Throughout the whole of his career in Bristol, Barker carried heavy administrative responsibilities, and the development of the Long Ashton Research Station and of the work of the University Advisory Centre until his retirement in 1943 are fitting memorials to his administrative ability and seientific vision. But his work did not end here. Throughout his career he somehow managed to continue with personal researches. Cider and cider-orcharding problems were always foremost in his programme, and the transformation of cider making from small farm enterprises to large-scale factory operations was in no small measure due to Barker's work. His unique knowledge of eider led to numerous calls on his services as a judge in national competitions, such as the Royal, the Bath and West and the Three Counties Agricultural Shows, and at the Brewers' Exhibition. In addition to his researches on cider, Barker made important contributions to pomology and to the mode of action of fungicides and insecticides, especially of Bordeaux mixture and sulphur compounds.

In the field of general horticulture he was for many years an examiner for the National Diploma in Horticulture of the Royal Horticultural Society, and with Sir Ronald Hatton was joint editor of the Journal of Pomology and Horticultural Science from 1924 until 1944. His services to horticulture were recognized by the Royal Horticultural Society by electing him an Honorary Fellow and by the award of a Veitch Memorial Trust Gold Medal. He was created C.B.E. in 1952.

Barker was a man of great personal charm and had many interests. In his younger days he was a keen player of cricket and hockey and also onjoyed tennis and billiards, while in his later years and after his retirement he was often to be seen enjoying a weekly round of golf on the Long Ashton course. He was an enthusiastic supporter of the University of Cambridge in rowing, cricket and rugby football, and, until prevented by illness in recent years, seldom failed to be present at the annual Cambridge-Oxford contests. He was also a talented pianist and a redoubtable chess player, and for many years he played regularly in county chess tournaments.

Because of his long career in science and his intimate contacts with agriculture and the cidor industry, and his many social activities, the passing of Prof. Barker will be felt deeply by a very wide circle of friends and colleagues. T. WALLAOE 